\title{
Production of Lily Symptomless Virus-free Plants by Shoot Meristem Tip Culture and In Vitro Thermotherapy
}

\author{
Beatrice Nesi ${ }^{1}$, Debora Trinchello, Sara Lazzereschi, and \\ Antonio Grassotti \\ C.R.A.-Research Unit for Nursery Production and Management of \\ Landscape and Ornamental Plants, Via dei Fiori 8, 51012 Pescia, Italy \\ Barbara Ruffoni \\ C.R.A.-Research Unit for Floriculture and Ornamental Plants, Corso degli \\ Inglesi 508, 18038 San Remo, Italy
}

Additional index words. micropropagation, meristem tip culture, RT-PCR, PAS-ELISA, thermotherapy

\begin{abstract}
To produce virus-free plants, a simple and original protocol was established by combining several techniques: repeated shoot meristem excision before and during in vitro culture and thermotherapy applied to bulblets in vitro. Lily symptomless virus (LSV) is a major virus that decreases plant growth vigor and the quality of cut flowers, yet infected plants show no distinct symptoms. Stock bulbs of pollenless Asiatic hybrid lily (L. $\times$ elegans Thunb) lines ('409' and '599') were used as explant. Shoot meristems were excised and micropropagated. Thermotherapy $\left(42\right.$ days at $\left.35^{\circ} \mathrm{C}\right)$ was applied to in vitro growing bulblets and a second meristem cut was then made from heat-treated material. Leaf tissues from bulblets formed before or postheat treatments were analyzed either by enzyme-linked immunosorbent assay or by reverse transcriptase-polymerase chain reaction. Line '499' produced LSV-free plants without heat treatment, but line '599' produced LSV-free plants only after heat treatment. The virus-free lily bulblets grew vigorously in vitro and acclimatized promptly. It is suggested that thermotherapy given to in vitro growing bulblets effectively eliminated the virus and induced a fast and efficient micropropagation technique for virus-free mother plant stock.
\end{abstract}

Lilies have become the most important floral crop in Italy in the last 20 years and this has created a need to produce high-quality, healthy bulbs free from virus. More than one hundred million lily bulbs are imported from abroad every year, so the availability of cultivars that were bred and suitable for culture under Italian environments, particularly hot weather, could be strategic for national production. Since 1983, commercially available Asiatic hybrid (Lilium $\times$ elegans Thunb) lily cultivars and other native species were exposed to x-ray irradiation to create new genotypes (Grassotti et al., 1989). Progenies with commercial traits, i.e., the ability to be grown outdoors in summer, new flower shapes and colors, high Bulbils formation, resistance to Botrytis elliptica, and

Received for publication 25 Oct. 2007. Accepted for publication 1 Nov. 2008.

This research was carried out with the contribution of the Italian Ministry of Agriculture, project VIVAFLOR, pubbl. N. 1.

We thank Dr. Maria Grazia Bellardi, University of Bologna (I) Department of Sciences and Agroenvironmental Technologies, for assisting with enzyme-linked immunosorbent assay tests.

${ }^{1}$ To whom reprint requests should be addressed; e-mail beatrice.nesi@entecra.it. the lack of pollen production, have been selected (Grassotti et al., 1996).

Commercial lilies have shown symptoms of virus infections after years of asexual propagation and culture in the field. Production for virus-free plants must be developed to produce quality plants and avoid developmental abnormalities. Micropropagation protocols in vitro have been developed to produce virus-free lily propagules (Spiegel, 2006). In many lilies, lily symptomless virus (LSV) has received special attention because it decreases plant vigor and production despite an apparent symptomless behavior.

Fungi and bacteria are removed during the establishment of in vitro cultures from standard sterilization of bulb scales, whereas viruses are not. Viruses can be eliminated by heat treatments of in vivo plants and bulbs (Ten Houten et al., 1968). The detection of viral agents in micropropagated plant cultures has been traditionally achieved by enzyme-linked immunosorbent assay (ELISA), but the sensitivity is low compared with recently introduced polymerase chain reaction techniques (Spiegel, 2006). Reverse transcriptase-polymerase chain reaction (RTPCR) was used for detection of a Tomato Aspermy Virus isolate that infected Chrysanthemum (Verma et al., 2006) and lilies (Niimi et al., 2003). RT-PCR has also been used to detect and study the biodiversity of 44 isolates of Cucumber Mosaic Virus and other virus strains (Anonymous, 1998). Pasquini and Barba (2001) used the RT-PCR method for detection of Plum Pox Virus in stone fruit trees. RT-PCR has been used in Lilium to compare the efficiency of the ELISA test in several plants of three lily cultivars of fieldgrown plants (Niimi et al., 2003) but has not been applied to verify the sanitary status of in vitro meristem-derived plants. Han et al. (2006) obtained a good percentage of virusfree material in vitro by using anther-derived callus in Lilium $\times$ 'Enchantment', but this method may induce somaclonal variants. We hypothesized that heat treatment given to bulblets already in vitro culture could be more effective to inactivate viruses. We report here a new program to develop virus-free lily plants combining techniques such as repeated meristem excision, meristem tip culture, and in vitro thermotherapy. Further efficiency of detection by ELISA and RT-PCR as influenced by genetic lines is discussed.

\section{Material and Methods}

Plant material and in vitro culture conditions. To set up an in vitro multiplication protocol, bulb scales were separated from bulbs stored at $10{ }^{\circ} \mathrm{C}$ of pollenless Asiatic hybrid lily (L. $\times$ elegans Thunb) lines '409' (unknown cultivar $\times$ 'Primavera') and '599' ('Connecticut King' $\times$ 'Silvia'). They were sterilized with $1.25 \%$ sodium hypochlorite solution for $15 \mathrm{~min}$ and rinsed twice with distilled sterile water. Scales were placed in a Murashige and Skoog (1962) (MS) basal medium supplemented with $2 \mathrm{mg} \cdot \mathrm{L}^{-1}$ benzyladenine acid (BA), $0.2 \mathrm{mg} \cdot \mathrm{L}^{-1}$ napthaleneacetic acid (NAA), $60 \mathrm{~g} \cdot \mathrm{L}^{-1}$ sucrose, $7 \mathrm{~g} \cdot \mathrm{L}^{-1}$ agar, $\mathrm{pH} 5.7$ (multiplication medium). They were cultured at $16-\mathrm{h}$ photoperiod, 35 $\mu \mathrm{mol} \cdot \mathrm{m}^{-2} \cdot \mathrm{s}^{-1}$, or in the dark at $23{ }^{\circ} \mathrm{C} \pm 2$ for bulblet formation at the base of scales. The bulblets formed in vitro were separated from the scales, and each individual bulblet was used in all subsequent experiments and tests.

The bulblets with scaly leaves and shoots were then grown for $15 \mathrm{~d}$ on hormone-free MS medium with $30 \mathrm{~g} \cdot \mathrm{L}^{-1}$ sucrose at $23{ }^{\circ} \mathrm{C} \pm 2$ in dark. Plants were transferred to the same base medium that was supplemented with 0.5 $\mathrm{mg} \cdot \mathrm{L}^{-1}$ indolebutyric acid (IBA) to induce multiple bulblets and cultured under light as previously described for $30 \mathrm{~d}$. Bulblets were transferred to a hormone-free MS medium with $30 \mathrm{~g} \cdot \mathrm{L}^{-1}$ sucrose to induce root formation. When roots had developed, bulblets (plants) were planted in pots filled with peat:perlite substrate (1:1 by volume) and acclimatized in a greenhouse maintained at $80 \%$ relative humidity controlled by an electronic leaf and $50 \%$ shading. After $15 \mathrm{~d}$, the humidity was reduced gradually to $50 \%$.

Shoot meristem tip culture and thermotherapy. Meristems without shoot primordia $(\approx 0.3 \mathrm{~mm}$ long) were aseptically excised from 20 bulbs stored at $10{ }^{\circ} \mathrm{C}$ and plated in petri dishes with MS basal medium supplemented with $60 \mathrm{~g} \cdot \mathrm{L}^{-1}$ sucrose, $7 \mathrm{~g} \cdot \mathrm{L}^{-1}$ 
agar, $\mathrm{pH}$ 5.7, and grown in the dark for $40 \mathrm{~d}$ to obtain virus-free plants. Shoots were placed on multiplication medium as previously described, and tissue samples were collected to detect the presence of LSV by ELISA when scaly leaves became $3 \mathrm{~cm}$ long. The presence of LSV was also determined by RT-PCR. To inactivate LSV, meristemderived bulbs were cultured aseptically using multiplication medium for $42 \mathrm{~d}$ in the dark maintained at $35^{\circ} \mathrm{C} \pm 1$. A second meristem cut was performed after heat treatment, and shoot apices were obtained and cultured in dark for $15 \mathrm{~d}$ in hormone-free MS medium and then transferred to the same medium and conditions previously described. After 90 d, a second RT-PCR test was performed using leaf samples.

Immunoenzymatic enzyme-linked immunosorbent assay test. Leaves collected from in vitro plants were tested for the presence of LSV by an indirect ELISA test. This method uses protein A in two applications to sandwich antibody-antigen-antibody layers as described by Edwards and Cooper (1985). The first applied layer of protein A prepares the plate for the coating antibody layer. The second layer of protein $\mathrm{A}$ is conjugated to the enzyme and detects the second antibody layer. Sera against LSV had been provided by University of Bologna, DiSTA-Patologia Vegetale Italy. Each sample was assayed four times.

Reverse transcription-polymerase chain reaction. Total RNA was extracted from $\approx 100 \mathrm{mg}$ of fresh leaves. Plant material was frozen in liquid nitrogen and homogenized with a mortar and pestle in $450 \mu \mathrm{L}$ of Buffer RLC following the procedures supplied with Qiagen's RNeasy Plant Mini Kit (Qiagen, Inc., Valencia, CA). The RNA concentration was determined by ultraviolet-VIS spectrophotometer (Ultrospek 3000; Pharmacia Biotech, Piscataway, NJ).

Degenerate primers (Operon Biotechnologies GmbH, Cologne, Germany) were used for RT-PCR amplification to detect LSV. These primers were designed according to amino acid sequences of coat protein in four LSV strains (LSVu and LSVd) and used to amplify a 483 bp-specific fragment from LSV by PCR (Niimi et al., 2003) (Table 1). Reverse transcription and PCR amplification were performed according to the information provided by Sigma's Enhanced Avian HS RT-PCR Kit (Sigma Aldrich Chemie GmbH, Steinheim, Germany). A one-step RT-PCR reaction was used to combine the eAMV-RT with the JumpStart AccuTaq LA Polymerase (Sigma Aldrich Chemie GmbH).

PCR was carried out in a $50 \mu \mathrm{L}$ reaction mixture containing $1 \mu \mathrm{g}$ template RNA, $3 \mathrm{mM} \mathrm{MgCl} 2,1 \mu \mathrm{M}$ of each specific primers, $200 \mu \mathrm{M}$ each dNTP, 0.05 units $/ \mu \mathrm{L}^{-1}$, the JumpStart AccuTaq LA DNA Polymerase, $1 \times$ reaction buffer, 0.4 units $/ \mu \mathrm{L}^{-1}$ of eAMV$\mathrm{RT}$, and 0.4 units $/ \mu \mathrm{L}^{-1}$ of RNAse inhibitor. The cycling program consisted of $50{ }^{\circ} \mathrm{C}$ for $50 \mathrm{~min}$, denaturation at $94{ }^{\circ} \mathrm{C}$ for $2 \mathrm{~min}$, 25 cycles at $94{ }^{\circ} \mathrm{C}$ for $15 \mathrm{~s}, 55^{\circ} \mathrm{C}$ for $30 \mathrm{~s}$, extension at $68^{\circ} \mathrm{C}$ for $1 \mathrm{~min}$, final extension
Table 1. Primer pairs for detection of lily symptomless virus used in reverse transcriptase-polymerase chain reaction. ${ }^{\mathrm{z}}$

\begin{tabular}{lcc}
\hline Primer sequence $\left(5^{\prime}-3^{\prime}\right)$ & Position $(\mathrm{bp})$ & $\begin{array}{c}\text { Fragment size } \\
\text { of amplicon }(\mathrm{bp})\end{array}$ \\
\hline Forward: GAYGARYTYTTYAARATGAARGT & $280-302$ & 483 \\
Reverse: ARYTGYTTRTGYGCRTTRTG & $761-742$ & \\
\hline
\end{tabular}

${ }^{\mathrm{z}} \mathrm{Y}=\mathrm{T}$ or $\mathrm{C} ; \mathrm{R}=\mathrm{A}$ or $\mathrm{G}$.

Table 2. Detection of lily symptomless virus by enzyme-linked immunosorbent assay (ELISA) and reverse transcriptase-polymerase chain reaction (RT-PCR) in leaf of in vitro bulbs of two pollenless lily genotypes as affected by shoot tip excision and heat treatment.

\begin{tabular}{llcc}
\hline Stage of shoot apex excision & Analysis & 409 & 599 \\
\hline A. Mother stock plants & ELISA & + & + \\
& RT-PCR & + & + \\
B. After the first meristem cut (first step) & ELISA & - & + \\
& RT-PCR & - & + \\
C. After thermotherapy + second meristem cut (second step) & ELISA & $\mathrm{nm}$ & $\mathrm{nm}$ \\
& RT-PCR & - & - \\
\hline
\end{tabular}

$+=$ positive $;-=$ negative, absence of band; $\mathrm{nm}=$ not made.

at $68^{\circ} \mathrm{C}$ for $5 \mathrm{~min}$, and finally hold at $12{ }^{\circ} \mathrm{C}$. Amplified samples were electrophoresed on $1 \%$ agarose gel in $1 \times$ TAE buffer with the size marker (100 bp DNA ladder). Gels were stained with ethidium bromide and observed under $254 \mathrm{~nm}$ ultraviolet light.

\section{Results}

The proposed protocol permitted an efficient propagation scheme. Bulb scales from ' 409 ' or ' 599 ' regenerated four to six bulblets from the base of each scale in $40 \mathrm{~d}$ from sterilization in multiplication medium when cultured in the darkness in the presence of BA and NAA. Scales cultured in the light (16-h photoperiod) developed four to six small bulblets with elongated shoots. Either bulbs or shoots, when transferred to IBAcontaining medium, developed as bulblets with scaly leaves. When leaves collected from bulblets developed from scales were checked for the presence of LSV by ELISA, '409' and '599' tested positive (Table 2). However, '409' tested negative for LSV after culture after the initial meristem isolation (first step), whereas all samples of '599' still tested positive (Table 2). The amplified banding patterns by RT-PCR confirmed the absence of LSV in '409' (Fig. 1, lane a) after the first meristem isolation. LSV was present in plants formed directly from the scale or after shoot tip culture in line ' 599 ' by ELISA (Table 2) and RT-PCR tests (Fig. 1, lanes $\mathrm{c}$ and d).

Shoot tips obtained from plants with etiolated leaves grew well and multiplied rapidly after the $42 \mathrm{~d}$ of $35^{\circ} \mathrm{C}$ heat treatment. Plants of ' 599 ' submitted to heat treatment and a second meristem cut (Fig. 2, lane a) did not demonstrate bands that indicate the presence of LSV and were considered virus-free. Virus-free bulblets were multiplied in vitro (Fig. 3) and transferred successfully for greenhouse culture after acclimatization (Fig. 4). Virus-free plants were more vigorous and produced more leaves than virus-infected plants after the first year of culture for bulb enlargement in the field.

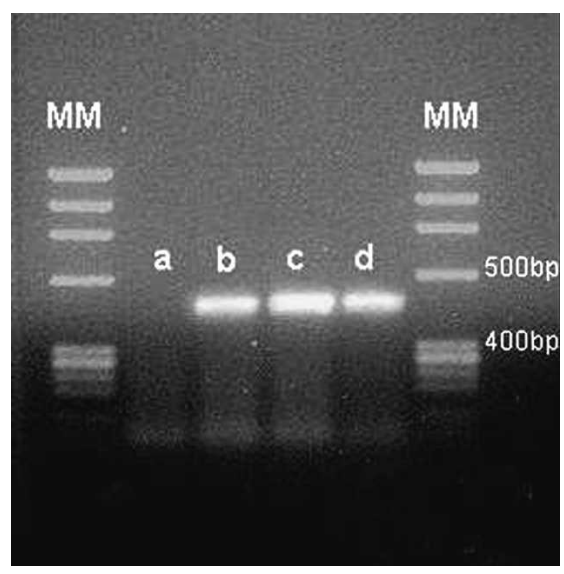

Fig. 1. The effect of shoot meristem tip culture on the elimination of lily symptomless virus in two lily genotypes, '409' and '599'. (A) '409' after single meristem excision; (B) '409' without meristem isolation; (C) '599' after a single meristem isolation; (D) '599' without meristem isolation.

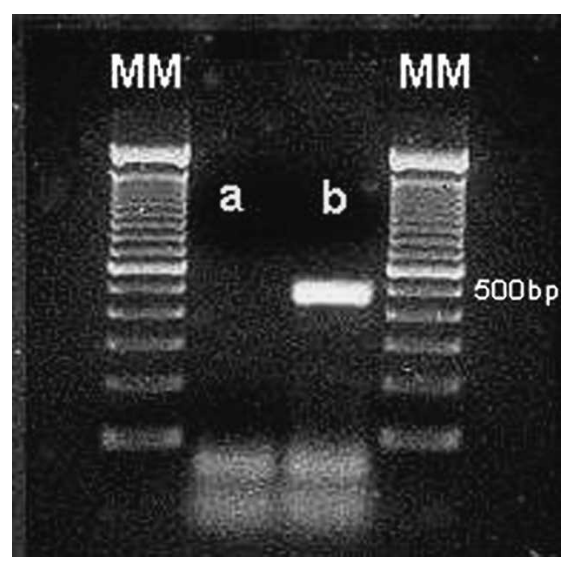

Fig. 2. The effect of thermotherapy and shoot meristem tip culture on the elimination of lily symptomless virus in lily genotype '599'. (A) '599' after thermotherapy and two meristem isolations; (B) '599' without thermotherapy after one meristem isolation. 


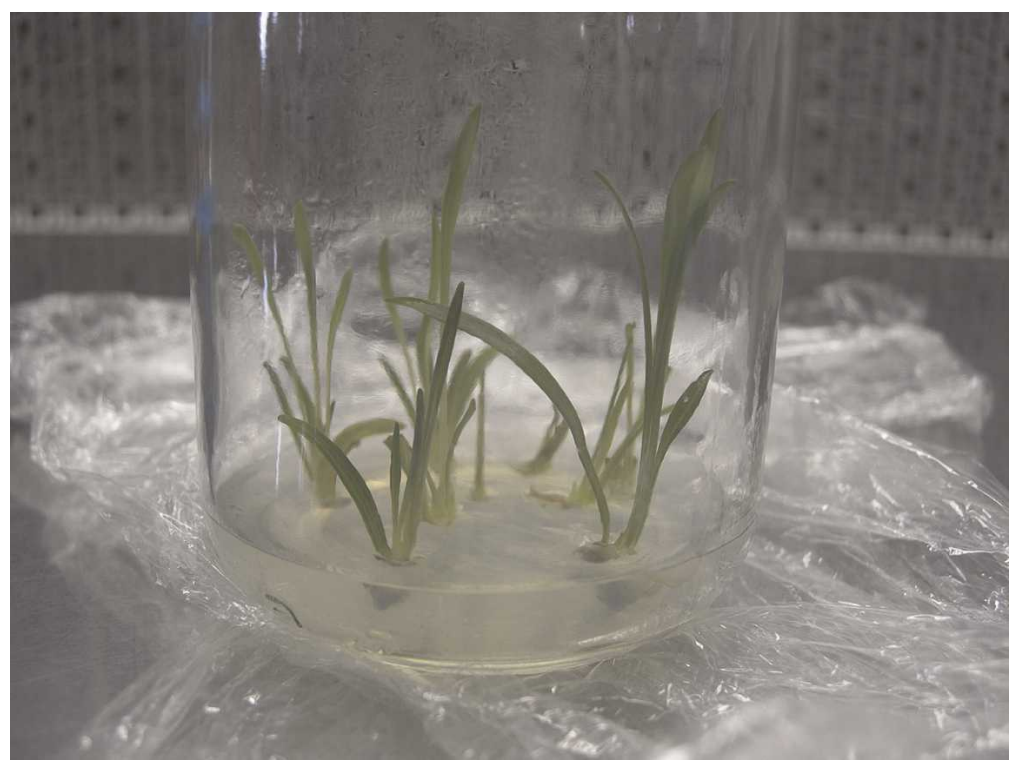

Fig. 3. In vitro propagation of lily bulbils ('409' virus-free) after transfer to Murashige and Skoog medium supplemented with $0.5 \mathrm{mg} \cdot \mathrm{L}^{-1}$ IBA in light $\left(16-\mathrm{h}\right.$ photoperiod, $\left.35 \mu \mathrm{mole} \cdot \mathrm{m}^{-2} \cdot \mathrm{s}^{-1}\right)$ at $23 \pm 2{ }^{\circ} \mathrm{C}$.

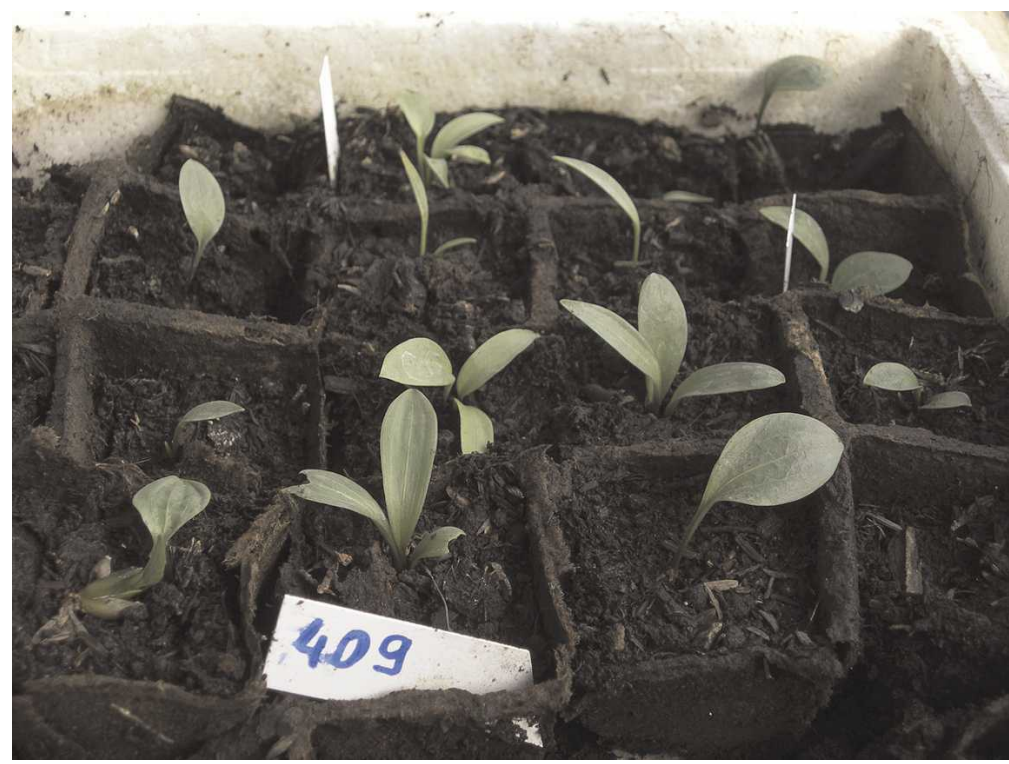

Fig. 4. Lily '409' virus-free plants acclimatized in the greenhouse 4 weeks after transfer.

\section{Discussion}

This study demonstrated that virus-free lilies can be produced by a combination of meristem cut, shoot tip culture, and thermotherapy. In many cases, meristem excision alone can successfully eliminate virus from infected plants (Ten Houten et al., 1968), and this is true in '409'. The effectiveness of this virus removal treatment depends on the genotype. When virus removal was not successful from a first meristem cut, heat treat- ment applied during in vitro culture effectively eliminated virus from plants of '599'. Although producing virus-free plants by shoot tip culture with or without heat treatment has been reported in many floral crops, this is the first report, to our knowledge, in which the efficacy of virus particle removal by shoot meristem tip culture and inactivation of virus particle by heat treatment depended on the genotype. Meristem tip culture methods would be better than callus culture as reported by Han et al. (2006) because the continuous proliferation of undifferentiated tissue during subculturing can increase the risk of genetic and/or epigenetic variations (Jain and De Klerk, 1998).

The increased effectiveness of RT-PCR to detect LSV in two genotypes compared with ELISA has been reported in Lilium for LSV and other viruses (Niimi et al., 2003). RTPCR was performed, in that case, in a twostep experiment. In this study, a one-step PCR was used successfully to amplify the viral sequence in lily. This protocol will permit the simplification of molecular detection for wider use in commercial laboratories.

\section{Literature Cited}

Anonymous,. 1998. Detection and biodiversity of Cucumber Mosaic Cucumovirus. Conclusions from a ringtest of EU cost 823. J. Plant Pathol. 80:133-149.

Edwards, M.L. and J.I. Cooper. 1985. Plant virus detection using a new form of indirect ELISA. J. Virol. Methods 11:309-313.

Grassotti, A., A. Mercuri, and M.S. Roh. 1996. Selection of Lilium for bulbil production characteristic. Acta Hort. 414:129-132

Grassotti, A., F. Torrini, A. Mercuri, and T. Schiva. 1989. Genetic improvement of Lilium in Italy. Acta Hort. 266:339-347.

Han, D.S., Y. Niimi, and S. Kimura. 2006. Localization of lily symptomless virus and Cucumber Mosaic Virus in anther- and filament-derived calluses and effect of callus culture duration on virus-free bulblets production in Lilium $\times$ 'Enchantment'. Plant Cell Tissue Organ Cult. $87: 211-217$

Jain, S.M. and G.J. De Klerk. 1998. Somaclonal variation in breeding and propagation of ornamental crops. Plant Tissue Culture and Biotech. 4:63-75.

Murashige, T. and F. Skoog. 1962. A revised medium for rapid growth and bioassays with tobacco tissue cultures. Physiol. Plant. 15:473497.

Niimi, Y., D.S. Han, S. Mori, and H. Kobayashi. 2003. Detection of Cucumber Mosaic virus, lily symptomless virus and lily mottle virus in Lilium species by RT-PCR technique. Sci. Hort. 97:57-63.

Pasquini, G. and M. Barba. 2001. The conservation of foliar samples an important aspect in the diagnostic of sharka virus (PPV). Project POM A32 Phytohealth rules and marketing of nursery productions, Locorotondo, Bari, Italy. Dec. 2001

Spiegel, S. 2006. Problems associated with in vitro culture propagation and virus detection. Acta Hort. 722:79-82.

Ten Houten, J.G., F. Quak, and F.A. van der Meer. 1968. Heat treatment and meristem culture for the production of virus-free plant material. Neth. J. Plant Pathol. 74:17-24.

Verma, N., K. Kumar, S. Kulshrestha, and I.D. Garg. 2006. Detection and molecular characterization of a Tomato Aspermy Virus isolate infecting Chrysanthemums in India. Acta Hort. 722:41-53. 